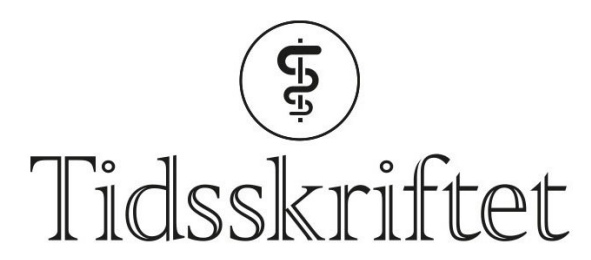

DEN NORSKE LEGEFORENING

\title{
Legemiddelbehandling gir lavere dødelighet hos heroinbrukere
}

FRA ANDRE TIDSSKRIFTER

KETIL SLAGSTAD

Tidsskriftet

Personer med opioidavhengighet har økt risiko for tidlig død. Behandling med legemidler reduserer dødeligheten, viser ny studie.

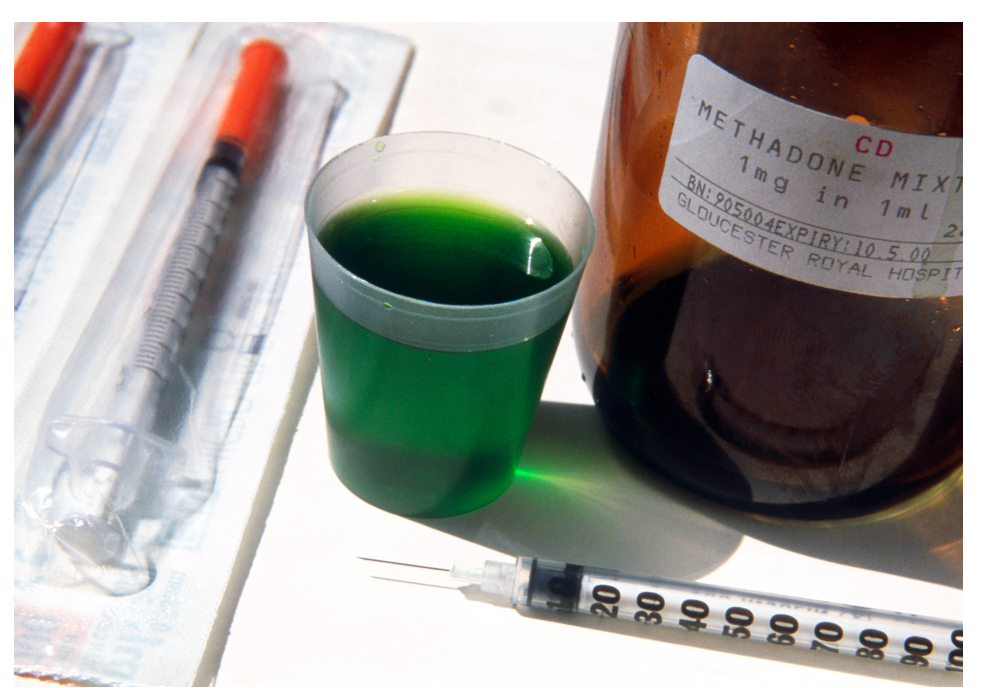

Illustrasjonsfoto: Science Photo Library

Legemiddelbasert rehabilitering ved opioidavhengighet, enten med metadon eller buprenorfin, reduserer dødeligheten. Det er mindre kjent om det er forskjell på legemidlene, og hvor lenge behandlingen bør vare.

En metaanalyse, nylig publisert i tidsskriftet BMJ, omfattet 19 kohortstudier med knapt 123 ooo pasienter behandlet med metadon og nesten 16 ooo med buprenorfin (1). Pasientene ble fulgt i flere år. Over 70\% var menn.

Totalmortaliteten varierte mellom studiene, men alle viste betraktelig høyere mortalitet i de gruppene som ikke fikk behandling. Der behandlingen ble avsluttet, $\varnothing$ kte dødeligheten igjen, særlig de første to ukene. Dødelighet på grunn av overdoser var også høyere i gruppen som ikke fikk behandling.

- Dette er en svært godt gjennomført metaanalyse, sier Helge Waal, professor emeritus ved Universitetet i Oslo. - Studien viser at vedlikeholdsbehandling med opioidagonister reduserer en ellers skremmende høy dødelighet hos heroinbrukere. 
- Overdosedødeligheten var vesentlig høyere de første fire ukene av behandlingen og økte igjen om behandlingen ble avsluttet. Det påligger altså et stort ansvar på legen om behandlingen avsluttes mot pasientens ønske, sier Waal.

- Studien har generert mye informasjon som kan bearbeides videre, bl.a. til å beregne hvor mange liv som spares med behandling, og for å sammenligne bruken av metadon mot buprenorfin. I metaanalyser er man avhengig av at de studiene som inkluderes, bruker samme variabler og er utformet på en bestemt måte for at de skal kunne inngå i samlede beregninger. Det kan derfor være vanskelig å overføre kunnskap fra metaanalyser til behandlingen av den enkelte pasient, sier Waal.

LITTERATUR:

1. Sordo L, Barrio G, Bravo MJ et al. Mortality risk during and after opioid substitution treatment: systematic review and meta-analysis of cohort studies. BMJ 2017; 357: j1550. [PubMed][CrossRef]

Publisert: 4. september 2017. Tidsskr Nor Legeforen. DOI: 10.4045/tidsskr.17.0547

(C) Tidsskrift for Den norske legeforening 2020. Lastet ned fra tidsskriftet.no 